\title{
BUCHer EsZTer
}

\section{NONPROFIT HOZZÁJÁRULÁS}

Hazánkban a rendszerváltozás óta eltelt két évtized alatt a nonprofit szektor jelentős számbeli gyarapodáson és minőségi fejlődésen ment keresztül, de a helyét a magyar társadalomban még ma is keresi. Az országban az 1980-as és 1990-es évek fordulóján végbement politikai, gazdasági és társadalmi átalakulás megnyitotta az utat a civil szféra kibontakozása előtt. A korábbi gátak megszűnésével a fejlődés robbanásszerủ volt. Egyre erősebben nyilvánultak meg azok a jelenségek, amelyek közösségi választ adtak a problémákra, szükségletekre. A nonprofit szektor létrejöttének egyik legfontosabb oka, hogy olyan új társadalmi igények jelentek meg, amelyeket sem az állami, sem a piaci szektor nem tudott biztosítani. A korábbi mindenható és gondoskodó állam visszaszorulásával nemcsak igény, hanem szükség is volt a társadalom önszerveződő csoportjainak egyre szélesebb tevékenységi kört felölelő feladatvállalására. Hazánkban a rendszerváltozást követően az állampolgároknak jóval nagyobb lehetőségük van arra, hogy közösségek formájában meghatározó szereplőivé váljanak a településeiket és térségeiket érintő feladatok alakításában. A társadalmi szerveződések számos olyan pozitív tulajdonsággal rendelkeznek, melyek indokolttá teszik szerepüket a terület- és településfejlesztés terén is. A civil szervezetek az állami, a piaci szektor és a társadalom tagjai között összekötő funkciót töltenek be, érdekérvényesítésre, -képviseletre képesek, hosszú távú jövőképpel, jelentős szabad kapacitással bírnak és emellett olyan helyismereti és kapcsolati tőkével rendelkeznek, melyek pótolhatatlanná teszik őket a helyi ügyek szervezésében, a térségeiket érintő fejlesztésekben. Az élhető környezet kialakításában a cél a társadalmi szereplők közötti együttműködés, melyet az Európai Unió is jelentős összegekkel támogat. A decentralizáció, a nyilvánosság, a részvétel, a partnerség és a szubszidiaritás elvei a civil szervezetek bevonását igénylik a területi, települési problémák megoldásába. Az uniós csatlakozás és a területfejlesztési törvény legutóbbi módosításai, ezen belül a civil fórumok létrehozásának ösztönzése egyszerre jelent kihívást és új lehetőségeket a terület- és településfejlesztés szereplői, köztük a nonprofit szervezetek számára (Kuti 1998: 123-220).

A nonprofit szervezetek közel kétharmada települési szinten müködik. A település lakosságának érdekeit, céljait, az alulról jövő kezdeményezéseket képviselik, így ezek a közösségek együttműködő partnerei lehetnek a települési önkormány- 
zatoknak. A települések a különféle érdekek megnyilvánulásának szinterei. A terület- és településfejlesztés céljaiban különböző helyi kezdeményezésű csoportok, az állam, az önkormányzat és a vállalkozók érdekei találkoznak és ütköznek meg (László - Köszegfalvi 2007: 63).

A nonprofit szektor újjáéledésének alapját a jogi keretek változásai tették lehetővé, mint a Polgári Törvénykönyv módosítása, az 1989-ben született egyesülési törvény, illetve a gyülekezési jogról szóló törvény ${ }^{1}$. Az 1990. évi LXV. törvény a helyi önkormányzatokról az első, amely - rámutatva a helyi kezdeményezések szükségességére - a decentralizációt tűzi ki célul. Fontosnak tartja, hogy minden problémát azon a szinten oldjanak meg, ahol keletkezett, erre pedig a helyi lakosság saját kezdeményezései a legalkalmasabbak. Jól érzékeli a helyi, települési szint és a civil kezdeményezések szerepét. Az 1997. évi CLVI törvény vezeti be a hármas minősítést: a nem közhasznú, közhasznứ ${ }^{2}$ és kiemelten közhasznú ${ }^{3}$ kategóriát. A legutolsó ebben a sorban a Nemzeti Civil Alapprogramról szóló 2003. évi L. törvény, amely a szféra lehetséges bevételeit bővíti, illetve a szektor kiteljesedését szolgálja. A törvény adta lehetőségeknek és céloknak megfelelően igen sokféle szervezet jött létre, melyek számos funkció betöltésére vállalkoztak. A nagy országos alapítványok, egyesületek mellett megtalálhatók az igen kis pénzből gazdálkodó és helyi, kis csoportok céljaiért harcoló civil szervezetek.

A nonprofit szervezetek tevékenységükkel támogatják a helyi önkormányzatokat feladataik ellátásában, ugyanakkor lehetőség szerint, anyagi támogatással és önkéntes munkával is segíthetik azt (Sebestyén 2002: 3-78). A civil szerevetek társadalmi, gazdasági ereje nem választható el egymástól, hiszen általában a két változó generálja és meghatározza egymást, kölcsönösen hatnak egymásra.

Jelen írásban egy, a mohácsi kistérségben végzett kutatás alapján igyekszünk bemutatni a nonprofit hozzájárulás sokszínűségét és végtelen lehetőségét, mely a kistérség gazdasági, társadalmi fejlődését közvetve vagy közvetlenül befolyásolja. Bár a kutatás csak a nemzetiségi alapon szerveződő civilekre terjed ki, alkalmas arra, hogy bemutassa a szervezetek ilyen irányú tevékenységét.

A népesség nemzetiségi értelmében vett sokszínűsége Baranya megyén (KSH 2003) belül leginkább a Mohácsi kistérségben figyelhető meg. Ezért vizsgálatunk helyszínéül a megjelölt kistérséget választottuk. A megyén belül kiemelkedően magas a magukat németnek, szerbnek, horvátnak, cigánynak vallók arány. A német nemzetiséghez tartozók aránya kiemelkedően magas a megyei $(3,5 \%)$ és

\footnotetext{
I Az I989. évi II. törvény az egyesülési jogról és azI989. évi III. törvény a gyülekezési jogról szóló törvény a szabad közösségalkotás elidegeníthetetlen jogát biztosította.

2 A közhasznú szervezetek szolgáltatásait tagjain kívül mások számára is elérhetővé teszi.

3 Állami feladatnak minősített feladatokat lát el és tevékenységéről a sajtó útján értesít.
} 
országos $(0,6 \%)$ adatokhoz képest. A kistérségben a német nyelvhez, közösséghez, kultúrához valamilyen módon kötődők aránya $13,5 \%$. A német nemzetiségi települések a kistérség településeinek több mint felét teszik ki (Bucher-Pirisi-Reményi 2008: 131). Sőt vannak olyan települések is, ahol a németség aránya meghaladja a 25\%-ot, egyes esetekben a 40-60\%-ot is (1. ábra). A magukat német nemzetiségűnek vallók aránya a népszámlálási adatokra támaszkodva a falvakban nagyobb, mint a városokban. Ennek történelmi okai vannak, és összefügg az urbanizációs folyamatokkal is. Kiinduló feltételezésünk, hogy a kistérség német nemzetiségi lakosságának közösségei, a civil szervezetek, kedvezően befolyásolják a lakóhelyük társadalmi-gazdasági fejlődését. A kutatás egyrészt meglévő statisztikai adatok és helytörténeti anyagok másodelemzésére épül, másrészt a helyi kisebbség civil szervezeteinek vezető személyeivel készített interjúkra támaszkodik.

1. ábra: Jelentös német nemzetiséggel rendelkezö települések a Mohácsi kistérségben

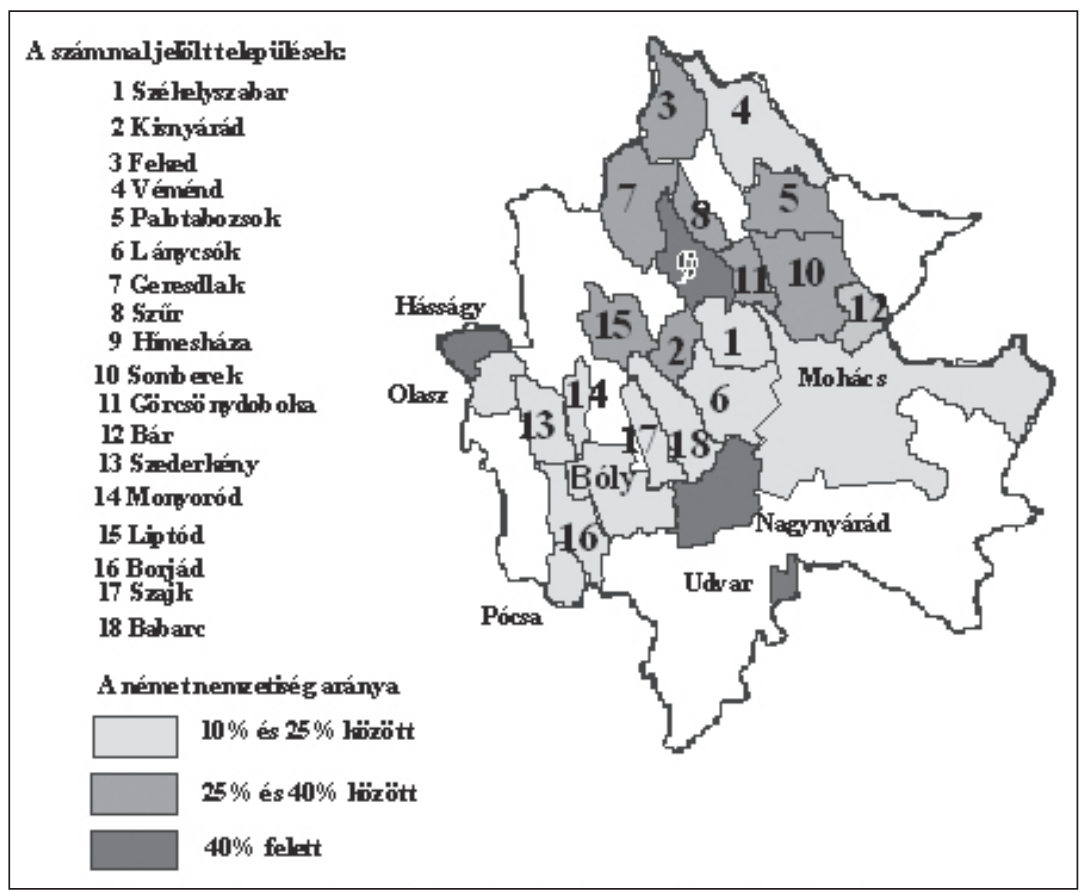

Forrás: A 2001-es népszámlálás adatai. Szerkesztette: Pirisi G. 


\section{A KISTÉRSÉG NEMZETISÉGI ALAPON SZERVEZŐDŐ KÖZÖSSÉGEINEK MÚLTJA}

A nemzetiségi alapon szerveződő civil szervezet létjogosultságát a történelem támasztja alá. A kézművesek céhekbe tömörült közössége jelentette az első kisebbségi alapon szerveződött önkéntes szervezeteket a térségben. A mohácsi kistérségbe a 18. században három hullámban betelepült svábok új szakmákat honosítottak meg, elsősorban a kézművesség és az agrárium területén (pl. borászat, szőlészet, dohánytermesztés). A kiegyezés után a legváltozatosabb egyesületi élet a gazdaságilag és kulturálisan sokszínü településeken alakult ki. A vármegye területén található 700 egyesület közel 10\%-a működött a kistérségben. Az egyesületek számának rohamos gyarapodásának másik oka a megváltozott jogszabályrendszerben keresendő. Ilyen például az 1864. évi 44. törvénycikk, amely kimondta, hogy bármely nemzetiségü honpolgárnak joga van „a nyelv, tudomány, gazdaság, ipar és kereskedelem előmozdítására szolgáló más intézmények mellett az állam törvény szabta felügyelete alatt társulásokba vagy egyletekbe összeállni”. A Mohács környéki települések esetében a törvényi változás kimondottan fontos, mivel a település soknemzetiségű és -vallású volt. A törvény lehetővé tette az itt élő kisebbségek számára nyelvük gyakorlását, kultúrájuk, hagyományaik megőrzését, amit szervezetekbe tömörülve, érdekeiket közösen képviselve tehettek meg (Márfi 1993: 292).

A dualizmus kora, mind a társadalmi, mind a gazdasági és a jogi feltételeket biztosította a helyi lakosság számára, hogy aktív közösségi életet éljen. Mohácson és Bólyban a civil szervezetek minőségi és innovációs szerepe ebben az időszakban kiemelkedő volt. Magas volt a kulturális és társadalmi, segélyező és szociális egyesületek száma. (Németbólyi Népnevelési Egylet, Olvasó Kör, Németbólyi Ipartestület, Németbólyi Kölcsönsegélyező Egylet, Mohácsi Casino Egylet, Dalárda). A két világháború közötti időszakban is számottevő volt a nonprofit szervezetek száma és szerepe, de már nem érte el a dualizmus kori fénykorát.

A szocializmus évei alatt a nemzetiségi alapon müködő öntevékeny közösségek, informális módon maradtak fenn.

A kistérség nemzetiségi civil szerveződései alapján elmondható, hogy ezek a közösségek már a 19. század első harmadában létrejöttek, nagyon erős kultúra, hagyomány és nyelvápolási célzattal. Azonban a német nyelv fennmaradása mellett a magyar nyelv tanulását is fontosnak tartották, mert ez biztosította a hatékonyabb érdekvédelmet és közösségeikben a magasan képzett emberfők kitermelését.

A rendszerváltozás a törvényi változások ismét lehetővé tették a közösségek szabad létrehozását és fejlődését. Ilyen törvények az 1990. évi LXV. törvény a helyi önkormányzatokról, az 1993. évi LXXVII. törvény a nemzeti és etnikai kisebbsé- 
gek jogairól. Másrészt a Polgári Törvénykönyv 1987-es módosítása és az 1989-ben születet egyesülési és gyülekezési jogról szóló törvény.

\section{A NÉMET NEMZETISÉGI ALAPON SZERVEZŐDŐ NONPROFIT SZER- VEZETEK TÁRSADALMI, GAZDASÁGI FUNKCIÓI}

A Mohácsi kistérség civil szervezeteinek több, mint 1/4-ét a kisebbségi alapon szerveződő közösségek teszik ki, közel 20\%-uk német nemzetiségi gyökerü. Tevékenységcsoport szerinti eloszlásuk nagymértékben eltér az országostól, mivel a kistérségben nagyon magas a kulturális nonprofit szervezet aránya. Minden negyedik szerveződés kulturális tevékenységű, de hasonlóan magas az oktatás szerepe. Ezek az adatok a térségben élő nemzetiségek arányaival magyarázhatók.

A civil szervezetek társadalmi-gazdasági ereje nem választható el egymástól, hiszen általában a két változó generálja és meghatározza egymást, kölcsönösen hatnak egymásra. Jelen munkában a német nemzetiségre, mint közösségre jellemző tulajdonságok gazdasági vonatkozásainak jellemzésére nem térek ki. Ilyenek a szorgalom, a takarékosság, a pontosság, melyek a németség legfőbb erényei (Barakonyiné 1993). Ezen tulajdonságok társadalmi-gazdasági szerepe tagadhatatlan. A civil szervezeteknek abban van küldetésszerủ feladatuk, hogy ezeket a pozitív értékeket megőrizze és ápolja.

\section{KÖZÖSSÉGFEJLESZTŐ KÉPESSÉG}

A civil szervezetek a társadalom alulról szerveződő közösségei, összekötik a hasonló értékeket valló - jelen esetben a német kultúrához, nyelvhez kötődő - lakosokat, és egységes erőt képeznek. A globalizálódó világban a kistérség helyi értékeit őrzik meg. A közösség így védeni tudja legfőbb értékeit, és hatékonyan tud fellépni céljaiért. A német nemzetiségi alapon szerveződő civil közösségek a kisebbségek jogait, érdekeit védik, hagyományaikat, kultúrájukat, és a jellegzetes sváb nyelvet ápolják és őrzik meg a fiatalabb nemzedékek számára.

\section{SZOLGÁLTATÁSOK}

A településeken működő német közösségek nem egyszerűen összefogják tagjaikat, hanem szolgáltatásokat nyújtanak, melyek mindenki előtt nyitottak. Az öntevékeny szervezetek előnye, hogy olyan szükségletekre képesek reagálni, amelyek nem a többség, hanem speciális helyzetben lévő társadalmi csoportok igényei. Ezek a szolgáltatások mindig emberibbek, innovatívabbak, mint az állami tucat jellegü szolgáltatások. E mellet az államtól, helyi önkormányzattól is vesznek át feladato- 
kat. Ennek leghatékonyabb módja a megbízásos szerződéses forma, és a normatív támogatás, amelyhez a szervezet hozzáteszi a saját forrásait. Ilyen szolgáltatások a kistérségben, melyeket a vizsgált szervezetek látnak el: az idősek gondozása, segítése, foglalkoztatása, karitatív tevékenységek, intézmények fenntartása, szakoktatás, nyelvi képzés, számítógépes oktatás, kulturális programok szervezése.

\section{KAPCSOLATI TŐKE TÁRSADALMI SZEREPE}

A nonprofit szervezetek nagy előnye, hogy ismeretségen, barátságon alapulnak, homogének, hasonló értékeket valló emberekből épülnek fel és mindennapi személyes kapcsolatot nyújtanak tagjaiknak. Ezen közösségek legnagyobb hozadéka a kapcsolati tókéjük, melynek szerepe a település életében kiemelkedő szerepet kap.

A helyi svábság kapcsolatai közül a legmeghatározóbb az anyaországhoz kötődő szoros szálak ápolása. A vizsgált nonprofit szervezetek mindegyike rendelkezik osztrák, illetve német társszervezettel. Nagyon fontosnak tartják ezeket az alulról szerveződő spontán baráti, családi kapcsolatokból elinduló és egyre szorosabbá váló kezdeményezéseket. Bóly esetében midenféle anyaországi szálnak ezek az egyszerű barátságok az alapjai. Rendszeres a hazai szervezetekből a kiutazás a német civil szervezetek szakmai tudásának megismerése és tapasztalatcsere céljából. Ismeretségük révén a települések intézményei, dolgozói, oktatói, diákjai csereoktatásban, nyelvi képzésben, szakmai továbbképzésben vesznek részt. A külföldi társszerveztek emellett jelentős gazdasági segítséget is nyújtanak adományok, természetbeni juttatások formájában. Többek között számítástechnikai eszközökkel, tanműhely működtetésével, kisebbségi, szociális intézmények fenntartásához szükséges anyagi hozzájárulással, német nyelvoktatással, tűzoltóautó adományozásával, egészségügyi eszközökkel, oktatási segédanyagokkal, gyerekjátékokkal. Ugyanilyen fontos, hogy az egyes helyi vegyes vállalatok alkalmazottjai hónapokat tanulnak és dolgoznak az anyacégnél Németországban, ahol a német szaknyelvet, munkamorált sajátítják el.

A testvérvárosi kapcsolatok jelentős része a vizsgált szerveződések kapcsolati tőkéjének eredményét jelentik. Hiszen a kapcsolatok alapja mindkét esetben két közösség személyes kapcsolatán és kontaktusán alapul, és ez teljesedik ki a települési szinten. Szederkény a helyi Honismereti Egyesületnek köszönheti létrejött partnerkapcsolatát. Bóly, Mohács és a kistérség települései ugyanezen az elven létesítettek testvérvárosi kapcsolatokat. Ezek a testvérvárosok gyakran a második világháború utáni kitelepítettek otthonai, más esetben az a térség, ahonnan a betelepítettek származnak (Baden-Württemberg, Hessen). 


\section{A KAPCSOLATI TŐKE GAZDASÁGI SZEREPE}

Ebben az esetben három tényező emelhető ki. Az egyik a német nyelv ismerete, melynek ápolásában a civil szervezetek fontos szerepet játszanak. A nyelvtudás az, ami ide vonzza a külföldi vállalkozásokat, melyek a gépipar területén működnek, és a német a szaknyelvük. A térségben a nyelvi ismereteket leginkább Bóly és Szederkény kamatoztatja, ami mindkét település munkanélküliségi mérőszámaiban is megmutatkozik. Bóly esetében a legnagyobb helyi vállalkozás tulajdonosa kitelepített németek leszármazottja, aki németországi vállalkozását kiterjesztette Magyarországra, és ennek helyszínéül ma is élő sváb rokonainak települését választotta.

Hasonló gazdaságélénkítő hatása van a falusi turizmusnak. Nagynyárád és Bóly kiemelkedik a turizmus ezen ágának művelésében. Számos faluban őrzik a német hagyományokat, kulturális közösségek formájában. Ezek a tánccsoportok, zenekarok, ősi mesterségek a térségbe csalogatják a turistákat. A falvak 20\%-a kapcsolódott be a falusi turizmusba. A kistelepüléseken a továbbélő hagyományok jelenthetik a falusi turizmus fejlesztésének alapjait, mely számos követelményt támaszt a résztvevő községek felé (rendezett településkép, minőségi alapszintủ ellátások megléte stb.). Ezek önmagukban is hozzájárulnak az életkörülmények fejlődéséhez. Megalakult a Dél-Dunántúli Német Nemzetiségi Falusi Turizmus Egyesület, amely az érdekképviseletben a közös marketingben és az oktatás területén nyújt segítséget tagjainak.

A helyi németség erős családi kapcsolatokkal rendelkezik: tagjaikhoz rendszeresen látogatnak el német és osztrák rokonaik, ez az ún. rokonturizmus. Ez ugyan nem jár kimagasló bevételekkel, azonban óriási propagandaértéke van. Ha a hozzánk látogatóknak vonzó és megfelelő minőségű programokat tudnak kínálni, ennek hírét tovább viszik és további, klasszikusnak mondható turizmust vonzanak. A rokonturizmus a legerősebben Nagynyárád, Hímesháza, Bóly, Szajk, Babarc, Bár és Szür településeken mutatkozik meg.

\section{ÖSSZEGZÉS}

A vizsgálatok eredményeként kijelenthető, hogy a kistérség településeinek gazdasági-társadalmi fejlődésében a górcső alá vett civil szervezeteknek meghatározó szerepük van. Hiszen azzal, hogy kulturális értéket, hagyományokat és a német nyelvet őrzik meg a jövő generációinak, már sokat tettek a fejlődés érdekében, és akkor még nem is említettük a tevékenységeikből eredő gazdasági hasznosságukat, amely kitörési, fejlődési lehetőséget nyújt a kistérség településeinek, hátrányos 
helyzetben lévő aprófalvainak. A civil szervezetek gazdasági-társadalmi hasznosságát egy olyan világban, ahol mindent pénzben mérnek, nagyon nehéz kimutatni. Hiszen hogyan lehetne kifejezni pénzbeli értéket egy hagyomány ápolásának, a kihalófélben lévő szakmák megőrzését, személyes kapcsolatokat, egy összetartó közösség értékét?

A kutatás elején megfogalmazott feltétélezést helyesnek mondhatjuk, azzal a kiegészítéssel, hogy települési és kistérségi szinten még jelentős erőt képeznek a vizsgált közösségi kezdeményezések, de nagyobb térségeket nézve nem képviselnek akkora erőt, hogy egymaguk változtassanak egy térség gazdasági fejlettségén.

\section{IRODALOM}

Bucher Eszter, Pirisi G. és Reményi P. (2008): Der Einfluss der Ungarndeutschen auf die gesellscahftlich-wirtschaftlicheEntwicklung Ungarnsinder RegionSüdtransdanubien. In Hammer, E. - Kupa László (szerk.): Ethno-Kulturelle Begegnungen in Mittel- und Osteuropa. Hamburg: Verlag Dr. Kovač, 131-146.

Barakonyiné Winiczai Klára (1993): Szorgalom, takarékosság, felhalmozás. Comitatus, 3 (9): 26-32.

Barakonyiné Winiczai Klára (2001): A sváb múlt nyomai Bóly társadalmában. Tér és Társadalom, 25 (3-4): 147-160.

Fukuyama, Francis (1995): Trust. The social virtues and the creation of prosperity. London: Hamish Hamilton, 5-27. (Magyarul: Bizalom. Budapest: Európa, 2007.)

Kuti Éva (1998): Hivjuk talán nonprofitnak. Budapest: Nonprofit Kutatócsoport.

Kuti Éva (2003): Gazdaságfejlesztési célú nonprofit szervezetek. Budapest: KSH.

KSH (2003): 20oI. évi Népszámlálás, Baranya megye II. Kötet. Budapest: KSH.

László Mária és Kőszegfalvi György (2007): A településfejlesztés cél- és eszközrendszere.

In László Mária és Pap Norbert (szerk.): Bevezetés a terület-és településfejlesztésbe. Pécs: Lomart, 63.

Márfi Attila (1993): Egyesületi élet Mohácson dualizmus időszakában. In Ódor Imre (szerk.): Tanulmányok Mohács Történetéböl. Mohács, 291-311.

Pavluska Valéria (1999): A nonprofit szektor. Pécs: JPTE Felnőttképzési és Emberi Erőforrás Fejlesztési Intézet.

Sebestyén István (2002): Önkormányzatok és a nonprofit szervezetek kapcsolata 20oo. Budapest: KSH, 2-67. 